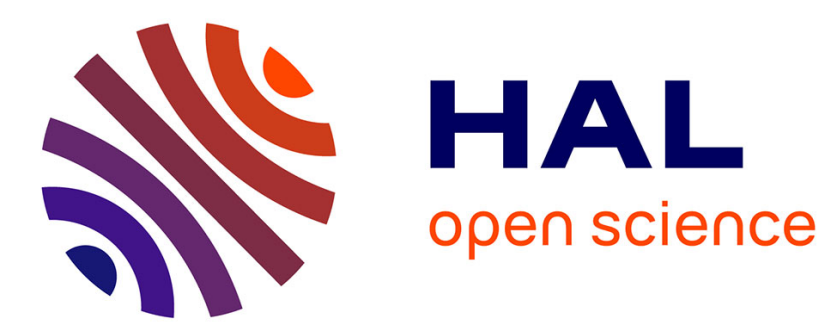

\title{
The Return of the Prodigy Son: Do Return Migrants make Better Leaders?
}

\author{
Marion Mercier
}

\section{To cite this version:}

Marion Mercier. The Return of the Prodigy Son: Do Return Migrants make Better Leaders?. 2013. halshs-00907277

\section{HAL Id: halshs-00907277 https://shs.hal.science/halshs-00907277}

Preprint submitted on 21 Nov 2013

HAL is a multi-disciplinary open access archive for the deposit and dissemination of scientific research documents, whether they are published or not. The documents may come from teaching and research institutions in France or abroad, or from public or private research centers.
L'archive ouverte pluridisciplinaire HAL, est destinée au dépôt et à la diffusion de documents scientifiques de niveau recherche, publiés ou non, émanant des établissements d'enseignement et de recherche français ou étrangers, des laboratoires publics ou privés. 


\section{PARISSCHOQL OF ECONOMICS}

WORKING PAPER N² $2013-37$

The Return of the Prodigy Son:

Do Return Migrants make Better Leaders?

Marion Mercier

JEL Codes: 011, E02, F22, N40

Keywords: Political leaders, Migration, Democracy, Developing countries

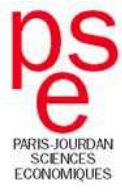




\title{
The Return of the Prodigy Son: Do Return Migrants make Better Leaders?
}

\author{
Marion Mercier*
}

\section{Abstract}

This paper investigates the impact of political leaders' migration experience on the quality of their leadership. We build up an original database on the personal background of 932 politicians who were at the head of the executive power in a developing country over the 1960-2004 period. We put forward a positive effect of the leader having studied abroad on the level of democracy in his country during his tenure. This effect is shown to be independent from the leader's education level, as well as from his profession. Moreover, it is mainly driven by countries with a poor initial level of democracy. These results are confirmed by various robustness tests. They propose a new channel through which migration may affect politics in the sending countries, namely the emergence of the elites.

Key words: political leaders, migration, democracy, developing countries.

JEL codes: O11, E02, F22, N40.

\footnotetext{
*Paris School of Economics, DIAL - IRD, mercier@dial.prd.fr
}

I wish to thank Lisa Chauvet, Paul Collier, Amelie Constant, David de la Croix, Frédéric Docquier, Flore Gubert, Gianmarco Leon, Fabio Mariani, Florian Mayneris, Arthur Silve, Ragnar Torvik, Thierry Verdier and Ekaterina Zhuravskaya for very helpful comments. I also thank the participants to the IZA $10^{t h}$ Annual Migration Meeting, to the second DIAL Development Conference and to the $4^{\text {th }}$ International Conference on Economics of Global Interactions for useful discussions. Finally, I wish to warmly thank the scientific committee of the latter conference for having granted the first Wim Meeusen Prize to this paper. 


\section{Introduction}

Recent as well as ancient history of the world has been marked by some individual personalities who played an important role either in major events (economic, political, cultural, etc.) or in the construction of ideologies and intellectual trends, or both. This in particular the case of certain political figures, such as Joseph Stalin, Felix Houphouët-Boigny or Indira Gandhi. When reaching the highest functions, political leaders become likely to shape the development path of their country, which may have long-run consequences.

Although they may be constrained in their actions through different national mechanisms, such as checks and balances or strong armies, leaders of the executive power undoubtedly play a potentially major role in the political and economic evolution of the country they are at the head of. Jones and Olken (2005) find that individual leaders have had a crucial impact on the growth pattern and policy outcomes of their countries since 1945. Leaders' effects are shown to be more important in autocratic settings, where their actions are less constrained. Thus, leaders have an individual impact on country-level economic and political outcomes. Following this result, one associated question emerges: which individual characteristics of the leaders affect the quality of their leadership and the development outcomes of their country? Besley, Montalvo, and ReynalQuerol (2011) started investigating this issue by studying the impact of leaders' education, and emphasized a positive and significant impact of leaders' educational attainment on growth. In this paper, we propose a different perspective in two respects: first, we question the impact of leaders' characteristics on democracy in developing countries, an outcome that has never been tested by the literature to date. Second, thanks to the original data at hand, we specifically document the impact of leaders' migration experience on their country's outcome.

The first contribution of this paper is to build up a new database gathering information on the personal characteristics of 932 leaders who were at the head of a developing country between 1960 and 2004. In particular the data document their migration history, an information that, to our knowledge, was not available in any existing database. Its second contribution is to provide original evidence about one specific channel through which migration may impact politics in the home country: namely, the emergence of national elites.

Anecdotal evidence clearly shows that a lot of leaders in the developing world had a migration experience before reaching power. It is much less clear whether these migration experiences affect the quality of their leadership, and in which direction. Some cases suggest that leaders who lived abroad in their past are prone to promote democracy. For instance, after having realized part of his studies in Russia, Punsalmaagiin Ochirbat led the Mongolian 1990 Democratic Revolution. During the seven following years that he spent in power, he accompanied his country toward the stabilization of democracy. On the contrary, history also 
provides instances of autocrats with an experience abroad. This is the case of Saddam Hussein, President of Iraq between 1979 and 2003, who studied in Egypt, or of Bashar al-Assad, President of Syria since 2000, who was trained in ophthalmology in the United Kingdom.

Beyond anecdotal evidence, the literature does not provide a systematic quantitative analysis of the impact of leaders' migration history on the quality of the institutions they lead. This paper aims at filling this gap. Thanks to the data at hand, we assess the effect of different types of migration experiences of the leaders on democracy in their country. While migration per se is not found to affect the quality of political institutions, it appears that leaders who studied abroad are associated with higher levels of democracy. We identify different theoretical mechanisms that could explain this positive correlation and implement specific empirical tests to disentangle them.

The rest of the paper is organized as follows: next section briefly summarizes the related literature, both regarding the impact of leaders and regarding the effects of migration on politics in the sending country. Section 3 presents the data that were collected for this study. Benchmark results and the different theoretical mechanisms potentially at play are presented in Section 4. We display empirical tests to investigate these different channels in Sections 5, 6 and 7. Robustness checks are implemented in Section 8 and Section 9 finally concludes.

\section{Literature review}

\subsection{Do decision-makers matter?}

The impact of individual decision-makers on aggregate outcomes is an important question in economics. The literature has already tackled this issue, as well as the extent and personal determinants of individuals' influence, notably in the frames of firms and of central banks. Focusing on firm heads, Bertrand and Schoar (2003) build an original data set that allows them to track individual managers during their whole career across different firms. Thanks to these data, they are able to estimate the impact of manager fixed effects on firm-level outcomes, controlling for year fixed effects as well as firm fixed effects and firm-level time-varying characteristics. They emphasize an important impact of individual managers on corporate practises and on firm performances. They also show that age and educational background partly explain the observed differences in the manager fixed effects. A few papers have also investigated the impact of central bankers' characteristics. In particular, Adolph (2004) shows that central bankers' career backgrounds affect different outcomes such as inflation or interest rates, as well as declared preferences. In a similar perspective, 
Göhlmann and Vaubel (2007) find, in a panel setting, that central bankers have different levels of aversion to inflation depending on their educational and occupational background.

As well as the characteristics of decision-makers may affect aggregate outcomes at the firm and central bank levels, the characteristics of political leaders may shape aggregate outcomes at the country level. This hypothesis is the basis of our paper, and has already been tackled by the economic literature. In a seminal paper, Jones and Olken (2005) examine the change in national leaders as an explanation of growth shifts. They rely on a data set gathering 130 countries over the 1945-2004 period, which represents 1,108 different national leaders for 1,294 distinct leadership periods. Investigating the impact of individual leaders on growth is challenging since it is reasonably arguable that switches in leadership are not random. Growth may in particular be an important determinant of the probability of leader change: for example, in democratic settings, incumbents have been shown to be more likely to be reelected during economic booms (Fair (1978)). Jones and Olken (2005) rely on an original strategy to assess the causal effect of leadership changes on growth: they identify leaders who died unexpectedly during their tenure, either because of a natural cause or in an accident, and thus exogenously left power. These cases of transitions provide natural experiments to study the impact of leadership changes on economic outcomes: in such cases, the timing of variation in the leadership is argued to be unrelated to underlying economic conditions. Thanks to this identification strategy, they find robust evidence that leaders matter for growth, especially in autocratic settings. They push the analysis further by investigating which policies are affected by individual leaders. Their results provide strong evidence that leaders have an impact on monetary policy, while fiscal, trade and security policies do not appear to be clearly affected. Putting forward a causative influence of political leaders on economic outcomes, in particular in non-democratic settings, this paper paved the way for further investigation on the role of leaders.

Logically following Jones and Olken (2005) results, as well as the literature documenting the impact of firm managers and central bankers, the question of the individual characteristics that affect the quality of leadership emerges. Besley, Montalvo, and Reynal-Querol (2011) go one step further in this direction by investigating the impact of leaders' education. They expand the data set used by Jones and Olken (2005) to 1848 , and collect information on education for a core sample of 1,654 leaders in 197 countries. They rely on the same identification strategy as Jones and Olken (2005), and allow leaders' effects to have an heterogenous impact on growth depending on educational attainment. They put forward a significant impact of leaders' education on growth: the more educated the leader who leaves power unexpectedly, the larger the adverse impact on economic growth. On the other hand, in a companion paper, Besley and Reynal- 
Querol (2011) question the process of choice of the leader by investigating the differences in educational attainment between leaders who are selected in democracies and leaders who are selected in autocracies. They emphasize an interesting result: democracies are shown to be more likely to select a highly educated leader. Taken together, these two papers suggest that, on the one hand, democracies select leaders differently regarding their educational background, and on the other hand, the educational background of the leaders affects their influence on growth. Education of the leaders is also put under study, together with professional background, by Dreher et al. (2009). This paper employs a panel data set over the 1970-2002 period, which gathers information on more than 500 political leaders from 73 countries, to investigate the impact of leaders' education and occupation on the implementation of market-liberalizing reforms. They find that former entrepreneurs and scientists tend to enhance reforms (measured by the Economic Freedom index from Gwartney, Lawson, and Norton (2008)), while former unionists have the opposite effect. The effect of profession is also shown to depend on the time spent in office: economists seem to be more reform-oriented only after a certain time in power. To our knowledge, these papers are the only existing quantitative studies on the individual characteristics that affect leaders' influence on country-level outcomes, either growth or liberalization reforms. Closely related to this literature, Franck and Rainer (2012) investigate the impact of leaders' ethnicity on infant mortality and education. Relying on individual data on a panel of 18 African countries, they show that being the coethnic of the political leader is strongly positively correlated with literacy and negatively with infant mortality. They thus provide evidence of ethnic favoritism through the individual identity of the leader.

Focusing on local leaders, Chattopadhyay and Duflo (2004) investigate the impact of women's leadership on policy decisions. They rely on a randomized policy experiment which consists in the reservation of one third of the Indian Village Council head positions for women. They investigate how this random treatment affects the provision of different local public goods. They find that political reservation for women in Indian local village councils induces a better access to public goods which are closely linked to women's concerns, like drinking water. Local leaders' gender thus appears to affect their political choices in this setting. In a recent work, Persson and Zhuravskaya (2011) study the impact of the personal characteristics of provincial leaders on the provision of local public goods and on rent extraction in China. They build a panel data set for 30 provinces of China over the 1986-2005 period, gathering information on the backgrounds and careers of provincial party secretaries. In particular, they collect information on the different places where provincial leaders worked before reaching this position, which allows them to identify party secretaries who have close ties to the local elites (the so-called local party secretaries). They show that these local party secretaries 
behave differently in terms of policy choices: namely, they reallocate public expenditure in education and health rather than in investment, provide more local public goods, and tend to extract less rent.

We build on this recent and promising literature on the personal characteristics of decision-makers. Thanks to the collection of original data, we investigate the impact of leaders' migration experience on the quality of leadership in the developing world over the 1960-2004 period. A second strand of the literature, which assesses the impact of migration on politics in the origin country, justifies asking this question.

\subsection{The impact of migration on the origin country}

The economic literature on migration and politics in the sending country underlines important interactions between them. Two main approaches developed, respectively on the macro and micro nexus between the different dimensions of migration and political outcomes. On the macro side first, and closely related to the problematic of this paper, Spilimbergo (2009) questions the impact of foreign education on democracy in the home country. Using a panel data set on foreign students starting in the 1950s, he finds that individuals educated abroad have a fostering effect on democracy in their home country, if this education is acquired in democratic countries. The author proposes five potential mechanisms through which education in a more democratic country can positively affect democracy in the origin country.

"First, foreign-educated "technocrats" [...] can impose their own preferences in favor of democratic regimes. Second, foreign-educated leaders seem to be extremely motivated to keep up with the more developed countries where they studied [...]. Third, foreign-educated individuals make it more difficult for dictatorial regimes to maintain repression, because they foster the dissemination of new ideas at home. Fourth, foreigneducated individuals can make repressive activities more costly for a dictatorial regime, since they have easier access to external media. [...] Fifth, education abroad may inculcate a sense of common identity with the international democratic community."

In this paper, we specifically investigate the second suggested channel, by focusing on leaders who lived (and, in certain cases, studied) abroad before reaching power. Still in this macro perspective, Docquier et al. (2011) document the effect of emigration on the home countries' institutions. In a panel setting, they investigate the impact of emigration rates, both total and skilled, on different measures of the quality of institutions in the home country (namely, the Political Rights and Civil Liberties indicators from Freedom House data set, the Polity score from Polity IV data set, and the Economic Freedom of the World index). Their empirical results show a positive effect of total emigration rate on the quality of political institutions in the sending country. The impact of skilled emigration is found to be ambiguous. They complement 
this econometric analysis by simulations thanks to which they put forward a generally positive impact of skilled emigration in the long run, once the impact of migration prospect on human capital formation in the sending country is taken into account. In the same vein, Lodigiani and Salomone (2012) find that international migration to countries with higher female political empowerment significantly increases the share of women in the origin country's parliament. Thus, on the macro side, the recent literature suggests a positive impact of emigration on the quality of political institutions, through total and skilled migration as well as through migration for studies. Nevertheless, the specific "leader" channel has never been investigated yet.

Recent micro evidence on migration and political behaviors is consistent with these macro results. Batista and Vicente (2011) rebuild the conditions of a referendum about political accountability and governance in Cape Verde. While conducting a household survey focusing on perceived corruption in the public sector, they offer respondents the possibility to anonymously send back a postcard asking for the disclosure of the survey's results by the media. They show that the proportion of international migrants (current and past) in the locality of the respondents is positively associated with their probability to send back this postcard. Thus emigration in general, and the presence of returnees in particular, are found to positively affect people's demand for political accountability. Moreover, the characteristics of the destination country seem to matter: the impact of migration on the demand for political accountability is higher when the destination country has better levels of governance. In a similar perspective, Pfutze (2012) investigates the impact of migration on the probability that a party in opposition to the former state party in Mexico wins a municipal election. He finds a positive impact of migration intensity on the electoral success of opposition parties. Omar Mahmoud et al. (2012) study the impact of migration on the support for the Communist party in the parliamentary elections in Moldova. They show that this support is lower in localities with more migration toward Western countries. They complement their locality-level analysis with an individual-level exit poll, which reveals that the probability that a non-migrant votes for the Communist party is negatively correlated with the prevalence of westward migration in his locality. Finally, Chauvet and Mercier (2013) study the impact of return migration on electoral behaviors in Mali and show that localities with a higher share of return migrants coming back from non-African countries exhibit higher participation rates to the local elections, as well as a more important level of electoral competitiveness. They also put forward a diffusion effect from returnees to non-migrants, who adopt different electoral norms when they live in more return migration intensive localities.

Both at the macro and at the micro level, these studies emphasize an important impact of migration 
intensity on politics in the home country, through more democratic institutions on the one hand, and through different individual behaviors and preferences on the other hand. This second strand of the literature thus supports the hypothesis that is under test in this paper, and encourages to ask whether leaders' migration experience affects the quality of their leadership.

\section{A new database on the characteristics of the leaders}

\subsection{Data collection}

We collected original data on the characteristics of a sample of leaders. We relied on the Archigos data base of political leaders from Goemans, Gleditsch, and Chiozza (2009), which identifies the primary ruler in each country and year over the 1875-2004 period. Starting from this data set, we selected the sample that is here under study, namely all the leaders at the head of a developing country between 1960 and 2004 . For each of these leaders, we then collected information on his personal and familial background, education, profession, military experience, and finally, migration experience. In particular, we looked for the duration, destination and objective of each migration period. Four objectives are distinguished: migration for studies, migration for diplomatic reasons, migration for military reasons other than war (such as military training), and exile. To gather these data, we relied on a range of web sources: the online Encylopedia Universalis, the biographies of political leaders published by the Barcelona Centre for International Affairs (CIDOB Centro de Estudios y Documentación Internacionales de Barcelona), Wikipedia, the websites of the national Parliaments and political parties, etc. Our final data base provides information on 932 leaders who headed 136 developing countries during 1,042 leadership periods between 1960 and 2004. For the empirical analysis that follows, we restrain this sample to leaders who stayed at least one year in power (see Section 3.3.1). This restriction make us end up with 679 leaders who headed 134 developing countries during 742 distinct leadership periods. Information on migration history is available for 610 of these leaders.

\subsection{Who are the leaders?}

Table 1 presents the main average characteristics of the leaders. Most of the 932 leaders in the developing world over the 1960-2004 period are men (97\%). In average, they reach power aged 51, and their tenure lasts five years and a half. Half of the leaders are highly educated. Following Besley and Reynal-Querol (2011), we define high education as having at least a master's degree (or equivalent). In their data set, less than $30 \%$ of the leaders are classified as educated. The difference with the proportion we observe in our sample 
is in line with the global spreading of education observed over the last century: while we concentrate on post-1960 leaders, their data start in 1848. Our database also contains information on leaders' profession. Ten categories are documented: army, law, economics, health, administration, academics, business, priests, scientists and workers. Military professionals are the most represented category ( $28 \%$ of the leaders), followed by lawyers (19\%). Academics gather $14 \%$ of the leaders and scientists and professionals of administration 9.5\% each. Then, around $8 \%$ of the leaders are economists. The four last categories are less represented: health professionals represent $5 \%$ of the leaders, businessmen $4 \%$, workers $3 \%$, and priests $1 \%$.

Table 1: Descriptive statistics

\begin{tabular}{lccc}
\hline & Average & $\begin{array}{c}\text { Standard } \\
\text { Deviation }\end{array}$ & Observations \\
\hline Woman & 0.03 & 0.16 & 932 \\
Age at arrival & 51 & 11 & $926^{a}$ \\
Tenure Duration (days) & 2012 & 2687 & 932 \\
High Education & 0.51 & 0.50 & 775 \\
Military & 0.28 & 0.45 & 792 \\
Law & 0.19 & 0.39 & 792 \\
Eco & 0.08 & 0.27 & 792 \\
Health & 0.05 & 0.22 & 792 \\
Admin & 0.09 & 0.28 & 792 \\
Academics & 0.14 & 0.34 & 792 \\
Worker & 0.03 & 0.18 & 792 \\
Religious & 0.01 & 0.12 & 792 \\
Scientist & 0.09 & 0.28 & 792 \\
Business & 0.04 & 0.21 & 792 \\
Migration & 0.68 & 0.47 & 786 \\
Mig - Diplomacy & 0.13 & 0.33 & 786 \\
Mig - Study & 0.41 & 0.49 & 786 \\
Mig - Exile & 0.14 & 0.34 & 786 \\
Mig - Military & 0.18 & 0.38 & 786 \\
Migration Duration (years) & 7 & 8 & 373 \\
\hline
\end{tabular}

${ }^{a}$ The date of birth of six leaders of the sample are not available.

Information on migration experience is available for 786 of the 932 leaders. ${ }^{1}$ Focusing on them, it clearly appears that migration has been a usual phenomenon within leaders in the developing world over the 19602004 period. Indeed, $68 \%$ of them had a migration experience before reaching power. Migration is very common within African (81\%), Latin American (72\%) and Asian (64\%) leaders. It is less the case regarding European leaders: $41 \%$ of them did live abroad before reaching power. We also have information on the type of migration. $13 \%$ of the leaders migrated for diplomatic reasons and $41 \%$ of them for studying. $14 \%$ of the leaders experienced an exile abroad. Finally, $18 \%$ of them lived abroad for military reasons. Taken

\footnotetext{
${ }^{1}$ This attrition may bias our results. We investigate this question in the next subsection.
} 
together, those migration experiences lasted in average seven years. Finally, we can identify the destinations of those migration experiences. The first destination is Europe, where $25 \%$ of the leaders migrated. $11 \%$ of them have lived in North America before reaching power, and 7\% in Africa. Asia and South America have been the destination of $6 \%$ and $5 \%$ of the leaders respectively. Less than $1 \%$ migrated to Oceania. Not surprisingly, the distribution of migration experiences across destinations varies according to the country of origin of the leaders. Notably, we observe important flows of "nearby migration": $25 \%$ of the African leaders migrated in Africa, which is the case of only $2 \%$ of the Asian leaders and less than $1 \%$ of the European and South American leaders. Symmetrically, $17 \%$ of the South American leaders migrated within their continent, while less than $1 \%$ of the African, European and Asian leaders went to Latin America. Migration toward North America is also much more common within South American leaders (23\% of them experienced it) than within leaders from the rest of the world (respectively $9 \%, 5 \%$ and $2 \%$ of the Asian, African and European leaders lived in North America). Finally, migration toward Europe is less discriminant: it concerned 37\% of the African leaders, $24 \%$ of the Asian leaders, $23 \%$ of the European leaders and $19 \%$ of the Latin American leaders.

\subsection{Sample}

Compared to the entire sample of 932 leaders, we perform our econometric estimations on a sub-sample that is restricted regarding two dimensions: first, we focus on the 679 "long-term" leaders, namely those who stayed in power at least one year, and second we do not have information on migration experience for 69 of those 679 leaders. The final usable sample is thus composed of 610 leaders, representing 668 leadership periods.

\subsubsection{Short-term vs. long-term leaders}

We restrict the sample to leaders who stayed at least one year in power for two reasons. First, from a practical point of view, this allows us to match our leader-level data to country-level data that are typically observed on a yearly basis. Second, from a theoretical point of view, leaders who spent a very short time span in power probably did not have enough time to implement the structural reforms that are necessary to the improvement of institutional quality. Excluding them from the sample thus diminishes the sources of noise in our estimations.

However, those leaders may be different to those who spent less than one year in power. Annex A presents the tests for the significance in the differences of leaders' characteristics between the group of short-tenure 
leaders (excluded from the empirical analysis) and the group of leaders who stayed at least one year in power. There is no significant differences between leaders who stayed more or less than one year in power regarding gender and regarding most of the professional backgrounds considered. Leaders who stay more than one year in power are found to reach power slightly younger (aged 51 in average) and, by construction, to stay longer (a bit more than seven years in average). Leaders who stay more than one year in power are in average less often highly educated. Importantly given the research question at stake here, they do not have a significantly different probability to have migrated before reaching power, neither a significantly different average migration duration. However, compared to those who stayed less than one year in power, they more often experienced an exile, and less often migrated for diplomatic reasons.

\subsubsection{Attrition issue}

Information on leaders' migration experience is available for 610 of the 679 leaders who stayed more than one year in power. We thus face an attrition issue. This attrition is less pronounced for the restricted sample of long-term leaders (attrition of 69 leaders, i.e. 11\% of the sample) than for the whole sample (attrition of 146 leaders over 932 , i.e. $16 \%$ of the sample). This is due to the fact that information on the characteristics of short-term leaders are less easily findable. Still, attrition remains a concern.

Table 2: Attrition issue

\begin{tabular}{|c|c|c|c|}
\hline \multirow{2}{*}{ Leader-level variables } & Difference & $(t$ statistics $)$ & Observations \\
\hline & & & \\
\hline Woman & -0.0246 & $(1.32)$ & 679 \\
\hline Year of arrival & -1.510 & $(0.77)$ & 679 \\
\hline Tenure Duration & $-1759.5^{* * *}$ & $(4.93)$ & 679 \\
\hline Age at arrival & -0.572 & $(0.42)$ & 678 \\
\hline \multicolumn{4}{|l|}{ Country-level variables } \\
\hline Africa & $-0.116^{* *}$ & $(2.05)$ & 679 \\
\hline Asia & 0.00297 & $(-0.05)$ & 679 \\
\hline South America & 0.0541 & $(-0.92)$ & 679 \\
\hline Europe & 0.0510 & $(-1.20)$ & 679 \\
\hline Polity score average & $-1.556^{*}$ & $(-1.80)$ & 627 \\
\hline Polity gap & $-1.014^{* *}$ & $(-2.01)$ & 627 \\
\hline Polity score at arrival & $-1.610^{*}$ & $(-1.82)$ & 615 \\
\hline
\end{tabular}

To have a better view on the potential consequences of this attrition, Table 2 presents the test of the significance in the differences between leaders who stayed more than one year in power for whom we do have and do not have information on migration experience, regarding leader-level and country-level variables. As expected, leaders for whom we do not find information on migration stayed in average less time in power. 
They are also relatively less located in Africa. Three political outcomes are tested: the average Polity score ${ }^{2}$ during the leader's tenure, the difference between the highest and lowest Polity scores recorded during the tenure, and the level of the Polity score when the leader reached power. It appears that leaders for whom we lack data on migration led countries with slightly lower levels of democracy, both measured in average and the year of their arrival. They are also characterized by a significantly smaller evolution observed in the Polity score during their tenure. This should be kept in mind when interpreting the empirical results. Moreover, in Annex B, we implement a specific test to shed light on the potential impact of this attrition bias on our benchmark results.

\section{Benchmark results}

To assess the impact of the leader's migration experience on democracy, we estimate Equation 1:

$$
\text { PolityScore }_{i, j, t}=\alpha+\text { SMigration }_{j}+\gamma X_{j}+\tau_{t}+\eta_{i}+\varepsilon_{i, j, t}
$$

The dependent variable is the average Polity Score in country $i$ during the period in power of leader $j$, who reached power at time $t$. Polity score, from the Polity IV dataset (Marshall and Jaggers (2002)), is an index of democracy provided by the Integrated Network for Societal Conflict Research (INSCR) of the Center for Systemic Peace. It assigns to each country an annual score in the autocracy-democracy spectrum, ranging from -10 (autocracy) to 10 (full democracy). We are interested in the impact on this democracy score of the migration experience of leader $j$, Migration $_{j}$. We introduce time dummies $\tau_{t}$ as well as country fixed effects $\eta_{i}$. We are thus able to control for all the time-invariant unobservable characteristics of the countries, and for all the country-invariant time trends. Moreover, we cluster standard errors at the country level to account for the potential within-country correlation of error terms.

We include a vector $X_{j}$ of leader-level controls composed of three variables: the duration of the tenure of leader $j$ (in days), a dummy equaling one if $j$ is a women, and an indicator of his education level. Following Besley, Montalvo, and Reynal-Querol (2011), we focus on a simple dichotomous variable to capture high versus non-high education. This dummy equals one when leader $j$ has at least a master's degree (or equivalent), and zero otherwise.

Column 1 of Table 3 presents the results of the estimation of Equation 1. As expected, the duration of

\footnotetext{
${ }^{2}$ Polity score, from the Polity IV dataset (Marshall and Jaggers (2002)), is an index of democracy provided by the Integrated Network for Societal Conflict Research (INSCR) of the Center for Systemic Peace. It assigns to each country an annual score in the autocracy-democracy spectrum, ranging from -10 (autocracy) to 10 (full democracy).
} 
the tenure is strongly negatively correlated with the quality of political institutions. On the contrary, we find positive coefficients of the Woman and High Education dummies. Turning to our variable of interest, the Migration dummy does not appear to be significantly correlated to democracy.

In a second step, we distinguish four types of migration: migration for studying, exile, migration for diplomacy, and for military reasons (other than war). Column 2 of Table 3 presents the estimation of Equation 2:

$$
\text { PolityScore }_{i, j, t}=\alpha+\delta_{1} \text { MigStudy }_{j}+\delta_{2} \text { MigExile }_{j}+\delta_{3} \text { MigDipl }_{j}+\delta_{4} \text { MigMilit }_{j}+\gamma X_{j}+\tau_{t}+\eta_{i}+\varepsilon_{i, j, t}
$$

When we split the migration variable in function of these four categories, the quality of political institutions appears to be positively and significantly associated with the leader having studied abroad. Exile of the leader is also positively associated with the Polity score, while the coefficient for migration for diplomatic motives is not significant. Finally, leaders who lived abroad for military reasons before reaching power are strongly negatively correlated with democracy in their countries. With this split of the Migration variable, the coefficients for the gender and education dummies decrease both in size and significance, high education turns out to be non significant, and the coefficient for the duration of the tenure remains very stable.

If migration per se is not significantly correlated with political outcomes, migrating for studying thus appears to be positively correlated with democracy, even controlling for high education, while migrating in a military context has the opposite effect. Finally, the experience of exile abroad seems to be positively correlated with democracy. Exile, migration for studies or for military activities of the leader could however be correlated with other country-level characteristics which themselves affect the quality of political institutions. Introducing country fixed effects allows us to rule out all such time-invariant country characteristics. Still, time-varying characteristics may matter. In Column 3, we add country-level control variables to capture these trends. We introduce the GDP per capita growth observed in country $i$ during leader $j$ 's tenure (using data from the Penn World Tables), which may be correlated with democratization. We also control for total and skilled emigration rates, in average during the leader's tenure (using data from Defoort (2008)). Since the probability of having a leader with a migration experience must be higher, all else equal, in countries that are characterized by a higher migration intensity, and since migration intensity may also directly affect democracy as suggested by Docquier et al. (2011), controlling for emigration rate is theoretically important. Moreover, population from the World Development Indicators is introduced. Finally, we control for the number of students abroad normalized by population, to account for the mechanism emphasized by Spilimbergo (2009). 
As shown in Column 3 however, the inclusion of these five variables does not weaken the estimated coefficients associated with the four migration variables, which size and significance become even larger.

Finally, migration of the leader could be correlated with other individual characteristics that may affect the quality of political institutions. This could in particular be the case of leaders' professions, which have been shown by Dreher et al. (2009) to have an impact on leaders' propensity to implement market-liberalizing reforms, and which are indeed correlated with migration experiences as shown in Annex C. In Column 4 of Table 3, we introduce as additional control variables ten different dummy variables for the profession of the leader. This is our preferred specification. Precisely, we introduce the following professional categories: army, law, economics, health, administration, academics, business, religion, science, and workers. Indeed, one could wonder if the exile or education (resp. military activity) abroad effects are driven by the occupational categories of the leaders. The results show that having studied abroad remains positively significant, while the coefficient associated to exile turns out to be non significant, as well as the negative impact of military activities abroad. We present the joint t-test of the ten profession variables at the bottom of the column. It shows that the different professions have indeed significant different impacts on the Polity score. In particular, the coefficient for being a professional military appears to be negative and significant. According to these last estimates, countries which leader has a foreign education background exhibit an average Polity score more than 1 point higher during the leader's tenure. 
Table 3: Benchmark estimations

\begin{tabular}{|c|c|c|c|c|}
\hline Dependent: Polity score & (1) & $(2)$ & $(3)$ & (4) \\
\hline Tenure duration & $\begin{array}{c}-0.000443^{* * *} \\
(0.000125)\end{array}$ & $\begin{array}{c}-0.000446^{* * *} \\
(0.000119)\end{array}$ & $\begin{array}{l}-0.000252 \\
(0.000209)\end{array}$ & $\begin{array}{l}-0.000192 \\
(0.000225)\end{array}$ \\
\hline Woman & $\begin{array}{c}2.660^{* * *} \\
(0.767)\end{array}$ & $\begin{array}{l}1.527^{* *} \\
(0.664)\end{array}$ & $\begin{array}{c}0.897 \\
(0.595)\end{array}$ & $\begin{array}{c}1.042 \\
(0.877)\end{array}$ \\
\hline High Education & $\begin{array}{c}1.729^{* * *} \\
(0.453)\end{array}$ & $\begin{array}{c}0.723 \\
(0.455)\end{array}$ & $\begin{array}{c}0.202 \\
(0.439)\end{array}$ & $\begin{array}{l}-0.229 \\
(0.567)\end{array}$ \\
\hline Migration & $\begin{array}{l}-0.438 \\
(0.446)\end{array}$ & & & \\
\hline Mig - Study & & $\begin{array}{l}0.771^{*} \\
(0.443)\end{array}$ & $\begin{array}{c}1.365^{* * *} \\
(0.489)\end{array}$ & $\begin{array}{l}1.276^{* *} \\
(0.500)\end{array}$ \\
\hline Mig - Exile & & $\begin{array}{c}0.965^{* *} \\
(0.432)\end{array}$ & $\begin{array}{c}1.049 * * \\
(0.441)\end{array}$ & $\begin{array}{c}0.0264 \\
(0.518)\end{array}$ \\
\hline Mig - Diplomacy & & $\begin{array}{l}-0.840 \\
(0.612)\end{array}$ & $\begin{array}{l}-0.312 \\
(0.759)\end{array}$ & $\begin{array}{l}-0.472 \\
(0.746)\end{array}$ \\
\hline Mig - Military & & $\begin{array}{c}-2.700^{* * *} \\
(0.693)\end{array}$ & $\begin{array}{c}-3.912^{* * *} \\
(0.794)\end{array}$ & $\begin{array}{c}0.122 \\
(1.258)\end{array}$ \\
\hline GDP pc growth (tenure) & & & $\begin{array}{c}-0.0768 \\
(0.112)\end{array}$ & $\begin{array}{l}0.0579 \\
(0.132)\end{array}$ \\
\hline Emig & & & $\begin{array}{c}14.24 \\
(15.03)\end{array}$ & $\begin{array}{c}14.12 \\
(16.00)\end{array}$ \\
\hline Skilled Emig & & & $\begin{array}{c}4.809 \\
(5.193)\end{array}$ & $\begin{array}{c}3.838 \\
(5.421)\end{array}$ \\
\hline Population & & & $\begin{array}{l}-8.39 \mathrm{e}-09 \\
(7.24 \mathrm{e}-09)\end{array}$ & $\begin{array}{l}-8.15 \mathrm{e}-09 \\
(8.11 \mathrm{e}-09)\end{array}$ \\
\hline Students abroad & & & $\begin{array}{l}-2.599 \\
(7.453)\end{array}$ & $\begin{array}{l}-6.584 \\
(7.373)\end{array}$ \\
\hline Law & & & & $\begin{array}{c}0.745 \\
(0.687)\end{array}$ \\
\hline Eco & & & & $\begin{array}{c}0.00816 \\
(0.856)\end{array}$ \\
\hline Health & & & & $\begin{array}{l}-0.619 \\
(1.402)\end{array}$ \\
\hline Military & & & & $\begin{array}{c}-4.560^{* * *} \\
(1.318)\end{array}$ \\
\hline Business & & & & $\begin{array}{l}-0.0708 \\
(0.913)\end{array}$ \\
\hline Admin & & & & $\begin{array}{c}0.291 \\
(0.903)\end{array}$ \\
\hline Academics & & & & $\begin{array}{l}-0.560 \\
(0.632)\end{array}$ \\
\hline Worker & & & & $\begin{array}{l}-0.0535 \\
(1.527)\end{array}$ \\
\hline Scientist & & & & $\begin{array}{c}0.246 \\
(0.936)\end{array}$ \\
\hline Religious & & & & $\begin{array}{c}1.425 \\
(1.638)\end{array}$ \\
\hline Constant & $\begin{array}{c}1.088 \\
(1.331)\end{array}$ & $\begin{array}{c}-1.024 \\
(1.369)\end{array}$ & $\begin{array}{c}3.199 \\
(1.967)\end{array}$ & $\begin{array}{c}2.535 \\
(2.247)\end{array}$ \\
\hline Observations & 577 & 577 & 403 & 377 \\
\hline R-squared & 0.510 & 0.554 & 0.614 & 0.643 \\
\hline Number of countries & 125 & 125 & 110 & 106 \\
\hline Country dummies & Yes & Yes & Yes & Yes \\
\hline $\begin{array}{l}\text { Year dummies } \\
\text { Joint t-test } \\
\text { (Profession dummies) }\end{array}$ & Yes & Yes & Yes & $\begin{array}{c}\text { Yes } \\
0.003\end{array}$ \\
\hline
\end{tabular}

Robust standard errors in parentheses, clustered at the country level.

$* * * \mathrm{p}<0.01,{ }^{*} * \mathrm{p}<0.05,{ }^{*} \mathrm{p}<0.1$. 


\section{Channels}

Studies abroad are positively correlated with democracy during the tenure. This correlation can reveal that future leaders who study abroad become more democratic, but it could also be driven by something else. We identify four theoretical mechanisms potentially at play.

1. The "democracies' preference" channel

First, the positive correlation between democracy and the leader having studied abroad may reveal that democratic countries prefer leaders with a migration background. Indeed, as Besley and ReynalQuerol (2011) emphasize that democracies select more educated leaders, one could also imagine that democracies select leaders who studied abroad. This story is consistent with the observed positive correlation between the level of democracy of the country during the leader's tenure and the dummy variable indicating whether he studied abroad. It predicts that this positive correlation should be driven by democratic countries, which have a preference for return migrants. The following Section is dedicated to the investigation of this channel.

2. Coming back when the tide is turning

Second, future leaders may come back from migration when their country starts democratizing. In particular, if emigration is triggered by dissatisfaction with respect to the home country's leadership, return migration may follow the first improvements of the political situation at home. The instance that epitomizes this channel is political exiles who flee their country during times of repression and start coming back (potentially already with the purpose of reaching power) when the political situation becomes friendlier. This story is also consistent with a positive correlation between the leader's migration background and the level of democracy in his country during his tenure. We implement empirical tests to identify whether this mechanism is leading our benchmark results in Section 6 .

\section{Selection issues}

Migration is not random, and an important strand of the literature - both theoretical and empirical emphasizes the important mechanisms of selection at play in the processes of migration and of return migration. The positive correlation that we observe between the migration of the leader and democracy during his tenure could also be biased by selection issues. Since migrants are selected, individuals (and among them future leaders) who migrate may have specific characteristics that make them more prone to democracy, and that would also have made them more prone to democracy had they not migrated. 
Section 7 deals with this selection bias through an empirical exercise aiming at isolating the decision to migrate and the propensity to be democrat.

4. Studies abroad make future leaders more prone to democratize?

Finally, the observed positive correlation may attest to a positive impact of foreign studies on the likelihood that the leader democratizes his country. This interpretation is in line with the recent developments of the literature on the impact of migration on politics at home presented in Section 2.2, according to which the experience of migration triggers transfers of political norms. Two different mechanisms, potentially simultaneously at play, may be at the root of this impact: the quality of education and the "preference shock". First, leaders who studied abroad may have benefited from higher quality training and thus have developed higher skills. As shown by Besley, Montalvo, and Reynal-Querol (2011), better educated leaders exhibit higher growth outcomes. In this perspective, one could imagine that better educated leaders also exhibit higher levels of democracy. If foreign studies are characterized by a higher quality than local education, their positive impact on leaders' propensity to democratize could reflect the fact that leaders who studied abroad reach a higher level of skills. Alternatively, while studying in a foreign country, future leaders may experience a "preference shock" that makes them more prone to democratize. This mechanism is in particular in line with the convergence hypothesis put forward by the literature on return migrants, which states that, while being abroad, migrants adopt specific behavioural norms to which they stick once back in their origin country. Following this story, the "preference shock" channel assumes that future leaders, while studying abroad, develop a higher preference for democracy, which translates into better levels of governance once they reached power.

\section{Do democracies prefer return migrants?}

The benchmark results put forward a positive correlation between studies abroad and democracy, even when controlling for leader-level and country-level variables. This positive correlation may reflect the fact that countries with more democratic institutions prefer and tend to select leaders who studied abroad (Channel 1, the "democracies' preference" channel). In this case, the coefficient would not reveal a better quality of the leadership, but different tastes in the selection of the leaders, depending on the prevailing level of democracy of the country. This issue is particularly relevant given the results emphasized by Besley and Reynal-Querol (2011) regarding the education of leaders. They show that democratic countries tend to select more educated 
leaders. Symmetrically, one could imagine that democracies have a higher propensity to choose leaders who studied abroad.

To test this issue, we introduce in our preferred specification (Column 4 of Table 3) the interactions between each type of migration and a dummy indicating if the country was initially an autocracy, Initially Autocratic. This variable is measured the first year of the leader's tenure. It equals one if the country had then a Polity score inferior or equal to zero, and zero otherwise. We also directly introduce this dummy within the vector of explanatory variables. In this specification, the coefficient associated with each migration variable corresponds to tenures which started in a relatively democratic context, while the correlation between each migration variable and democracy in initially autocratic countries is given by the coefficient associated with the migration variable plus the coefficient of its interaction with Initially Autocratic.

Table 4 presents the results. Not surprisingly, the Initially Autocratic dummy is significantly negative in all four specifications: countries in which the tenure started in an autocratic setting tend to have an average Polity score 9 points lower during the tenure. In Column 1, the Migration dummy is found to be non significant. However, its interaction with the Initially Autocratic dummy is significantly positive, suggesting that leaders of an initially autocratic country who experienced migration before reaching power are characterized by an average Polity score around 1 point higher during their tenure. In the three last columns, we split the Migration dummy in the four categories of migration experience, and successively introduce the different groups of control variables (leader-level controls - the duration of the tenure, gender and education of the leader -, country-level controls - GDP per capita growth, emigration and skilled emigration rates - and finally the ten profession dummies). In those three estimations, the coefficient for Mig - Study turns out to be non significant, and its interaction with Initially Autocratic is positive and significant. This suggests that, while the migration experience of the leader is not significantly associated with the quality of institutions when the tenure started in a relatively democratic setting, leaders who studied abroad are characterized by an average Polity score around 2 points higher when they reached power in an autocratic context. These results are exactly the opposite to what the "democracies' preference" channel suggests: the positive correlation between studies abroad and democracy is not due to the fact that democracies select return migrants but, on the contrary, it is driven by countries in which the tenure started with a negative Polity score, in other words by relatively autocratic countries. 
Table 4: Do democracies prefer return migrants?

\begin{tabular}{|c|c|c|c|c|}
\hline Dependent: Polity score & (1) & $(2)$ & $(3)$ & $(4)$ \\
\hline Initially Autocratic & $\begin{array}{c}-9.194^{* * *} \\
(0.753)\end{array}$ & $\begin{array}{c}-9.289^{* * *} \\
(0.683)\end{array}$ & $\begin{array}{c}-9.509 * * * \\
(0.854)\end{array}$ & $\begin{array}{c}-9.444^{* * *} \\
(0.913)\end{array}$ \\
\hline Migration & $\begin{array}{l}-0.470 \\
(0.373)\end{array}$ & & & \\
\hline Initially Autocratic x Migration & $\begin{array}{l}1.337^{*} \\
(0.684)\end{array}$ & & & \\
\hline Mig - Study & & $\begin{array}{l}-0.148 \\
(0.339)\end{array}$ & $\begin{array}{c}0.175 \\
(0.374)\end{array}$ & $\begin{array}{c}0.325 \\
(0.429)\end{array}$ \\
\hline Initially Autocratic x Mig - Study & & $\begin{array}{c}1.932^{* * *} \\
(0.634)\end{array}$ & $\begin{array}{c}2.554^{* * *} \\
(0.747)\end{array}$ & $\begin{array}{c}2.332^{* * *} \\
(0.762)\end{array}$ \\
\hline Mig - Exile & & $\begin{array}{l}-0.245 \\
(0.490)\end{array}$ & $\begin{array}{l}-0.396 \\
(0.515)\end{array}$ & $\begin{array}{l}-0.697 \\
(0.603)\end{array}$ \\
\hline Initially Autocratic x Mig - Exile & & $\begin{array}{c}0.925 \\
(0.847)\end{array}$ & $\begin{array}{c}2.304^{* *} \\
(1.112)\end{array}$ & $\begin{array}{c}2.510^{* *} \\
(1.261)\end{array}$ \\
\hline Mig - Diplomacy & & $\begin{array}{l}-0.755 \\
(0.628)\end{array}$ & $\begin{array}{l}-0.392 \\
(0.708)\end{array}$ & $\begin{array}{l}-0.546 \\
(0.779)\end{array}$ \\
\hline Initially Autocratic x Mig - Diplomacy & & $\begin{array}{c}0.959 \\
(0.904)\end{array}$ & $\begin{array}{c}0.406 \\
(1.134)\end{array}$ & $\begin{array}{c}0.618 \\
(1.356)\end{array}$ \\
\hline Mig - Military & & $\begin{array}{c}-1.232^{* *} \\
(0.597)\end{array}$ & $\begin{array}{c}-1.351^{* * *} \\
(0.475)\end{array}$ & $\begin{array}{l}-0.546 \\
(0.850)\end{array}$ \\
\hline Initially Autocratic x Mig - Military & & $\begin{array}{c}1.109 \\
(0.706)\end{array}$ & $\begin{array}{c}0.764 \\
(0.852)\end{array}$ & $\begin{array}{c}0.899 \\
(0.880)\end{array}$ \\
\hline Constant & $\begin{array}{c}6.314^{* * * *} \\
(0.975)\end{array}$ & $\begin{array}{c}6.376^{* * *} \\
(1.035)\end{array}$ & $\begin{array}{c}0.197 \\
(1.521)\end{array}$ & $\begin{array}{c}7.205^{* * *} \\
(1.607)\end{array}$ \\
\hline Observations & 577 & 577 & 403 & 377 \\
\hline R-squared & 0.813 & 0.822 & 0.840 & 0.840 \\
\hline Number of countries & 125 & 125 & 110 & 106 \\
\hline Leader level controls & Yes & Yes & Yes & Yes \\
\hline Country level controls & No & No & Yes & Yes \\
\hline Profession dummies & No & No & No & Yes \\
\hline Country dummies & Yes & Yes & Yes & Yes \\
\hline Year dummies & Yes & Yes & Yes & Yes \\
\hline
\end{tabular}

In Columns 2 and 3, migration for military reasons appears to be negatively correlated to democracy, both in initially autocratic and in initially democratic countries. As already observed in Table 3, this effect turns out to be non significant as soon as we introduce the leaders' profession dummies (Column 4). Exile is not significantly correlated with democracy in initially democratic settings, but its interaction with the Initially Autocratic dummy is significantly positive in Columns 3 and 4. This positive correlation between the leader having been exiled before reaching power and the level of democracy suggests a different source of endogeneity: the fact that future leaders of initially autocratic countries may come back from migration 
when the quality of institutions is starting to improve in their country, or come back in the specific objective to take power (Channel 2, "Coming back when the tide is turning"). This mechanism could also affect the Mig - Study variable. We will investigate it in the following section. Finally, migration for diplomatic reasons is never significantly correlated with democracy in Table 4, whatever the specification and the initial level of democracy.

\section{Do future leaders come back when the tide is turning?}

Table 4 shows that the positive correlation between studies abroad and democracy is not due to the fact that democracies select return migrants as leaders. However, it enlightens another mechanism that could drive the results, namely the fact that migrants, among them future leaders, may come back to their country of origin when it starts democratizing (Channel 2). This is in particular what suggests the positive and significant coefficient associated with the exile of the leader in initially autocratic settings in Columns 3 and 4 of Table 4. To capture this effect, we re-iterate the estimations of Table 4, adding as a supplementary control variable the average level of the Polity score observed during the previous leader's tenure. Results are shown in Columns 1 to 4 of Table 5 .

The level of democracy during the previous leader's tenure is found to be positively associated with the average democracy during the current leader's tenure. Turning to the migration variables, the results of the four specifications are very close to those observed in Table 4 regarding Mig - Study and its interaction with Initially Autocratic. Indeed, studies abroad remain significantly and positively associated with democracy for leaders who started their tenure in an autocratic setting, with a slightly smaller coefficient. On the contrary, the interaction between Mig - Exile and the Initially Autocratic dummy is now non significant in all specifications. This suggests that the significance of this coefficient observed in Table 4 was led by the mechanism described by Channel 2: future leaders coming back when the political situation starts being friendlier. 
Table 5: Controlling for past democracy

\begin{tabular}{|c|c|c|c|c|c|}
\hline Dependent: Polity score & $(1)$ & $(2)$ & $(3)$ & $(4)$ & $(5)$ \\
\hline Lagged Polity IV & $\begin{array}{c}0.124^{* * *} \\
(0.0322)\end{array}$ & $\begin{array}{c}0.116^{* * *} \\
(0.0322)\end{array}$ & $\begin{array}{c}0.0892^{* *} \\
(0.0357)\end{array}$ & $\begin{array}{c}0.100^{* *} \\
(0.0409)\end{array}$ & $\begin{array}{c}0.133 * * \\
(0.0632)\end{array}$ \\
\hline Initially Autocratic & $\begin{array}{c}-8.645^{* * *} \\
(0.734)\end{array}$ & $\begin{array}{c}-8.686^{* * *} \\
(0.666)\end{array}$ & $\begin{array}{c}-9.273^{* * *} \\
(0.876)\end{array}$ & $\begin{array}{c}-9.107^{* * * *} \\
(0.948)\end{array}$ & $\begin{array}{c}-9.736^{* * *} \\
(1.284)\end{array}$ \\
\hline Migration & $\begin{array}{l}-0.248 \\
(0.371)\end{array}$ & & & & \\
\hline Initially Autocratic x Migration & $\begin{array}{l}1.069 \\
(0.685)\end{array}$ & & & & \\
\hline Mig - Study & & $\begin{array}{l}-0.234 \\
(0.342)\end{array}$ & $\begin{array}{l}-0.197 \\
(0.334)\end{array}$ & $\begin{array}{l}-0.151 \\
(0.367)\end{array}$ & $\begin{array}{l}-0.137 \\
(0.340)\end{array}$ \\
\hline Initially Autocratic x Mig - Study & & $\begin{array}{c}1.898^{* * *} \\
(0.710)\end{array}$ & $\begin{array}{c}2.365^{* * *} \\
(0.762)\end{array}$ & $\begin{array}{c}1.993^{* * *} \\
(0.759)\end{array}$ & $\begin{array}{c}2.413^{* * *} \\
(0.669)\end{array}$ \\
\hline Mig - Exile & & $\begin{array}{c}0.206 \\
(0.427)\end{array}$ & $\begin{array}{c}0.154 \\
(0.479)\end{array}$ & $\begin{array}{l}-0.134 \\
(0.545)\end{array}$ & $\begin{array}{l}0.0373 \\
(0.415)\end{array}$ \\
\hline Initially Autocratic x Mig - Exile & & $\begin{array}{l}-0.150 \\
(0.737)\end{array}$ & $\begin{array}{c}0.697 \\
(0.928)\end{array}$ & $\begin{array}{c}0.705 \\
(1.103)\end{array}$ & $\begin{array}{c}0.853 \\
(1.206)\end{array}$ \\
\hline Mig - Diplomacy & & $\begin{array}{l}-0.490 \\
(0.472)\end{array}$ & $\begin{array}{l}-0.191 \\
(0.562)\end{array}$ & $\begin{array}{l}-0.431 \\
(0.654)\end{array}$ & $\begin{array}{l}-0.760 \\
(0.519)\end{array}$ \\
\hline Initially Autocratic x Mig - Diplomacy & & $\begin{array}{c}0.331 \\
(0.733)\end{array}$ & $\begin{array}{c}-0.00709 \\
(1.010)\end{array}$ & $\begin{array}{c}0.547 \\
(1.190)\end{array}$ & $\begin{array}{l}1.209 \\
(1.514)\end{array}$ \\
\hline Mig - Military & & $\begin{array}{l}-0.781 \\
(0.598)\end{array}$ & $\begin{array}{l}-0.999^{*} \\
(0.506)\end{array}$ & $\begin{array}{c}0.217 \\
(0.866)\end{array}$ & $\begin{array}{l}0.0665 \\
(1.156)\end{array}$ \\
\hline Initially Autocratic x Mig - Military & & $\begin{array}{c}0.949 \\
(0.687)\end{array}$ & $\begin{array}{c}0.751 \\
(0.857)\end{array}$ & $\begin{array}{c}0.812 \\
(0.856)\end{array}$ & $\begin{array}{c}0.0208 \\
(1.261)\end{array}$ \\
\hline Constant & $\begin{array}{c}5.578^{* * *} \\
(0.868)\end{array}$ & $\begin{array}{c}5.866^{* * *} \\
(0.924)\end{array}$ & $\begin{array}{c}3.133^{* *} \\
(1.362)\end{array}$ & $\begin{array}{c}3.423^{* *} \\
(1.703)\end{array}$ & \\
\hline Observations & 511 & 511 & 373 & 351 & 222 \\
\hline R-squared & 0.858 & 0.862 & 0.871 & 0.875 & \\
\hline Number of countries & 115 & 115 & 105 & 102 & 73 \\
\hline Leader level controls & Yes & Yes & Yes & Yes & Yes \\
\hline Country level controls & No & No & Yes & Yes & Yes \\
\hline Profession dummies & No & No & No & Yes & Yes \\
\hline Country dummies & Yes & Yes & Yes & Yes & No \\
\hline Year dummies & Yes & Yes & Yes & Yes & No \\
\hline AR(1) Test & & & & & 0.020 \\
\hline $\operatorname{AR}(2)$ Test & & & & & 0.591 \\
\hline Sargan Test & & & & & $0.077 / 0.998$ \\
\hline Number of instruments & & & & & 101 \\
\hline
\end{tabular}

Robust standard errors in parentheses, clustered at the country level. ${ }^{* * *} \mathrm{p}<0.01,{ }^{* *} \mathrm{p}<0.05,{ }^{*} \mathrm{p}<0.1$.

Leader level controls refer to: Tenure duration, Woman, High Education. Country level controls refer to: GDP pc growth (tenure), Emig, Skilled Emig, Pop and Students abroad normalized by population.

Introducing the previous level of democracy in Table 5 allows to be more confident regarding the fact that the positive correlation between studies abroad and democracy is not driven by future leaders coming back when the institutional quality improves in their home country. However, it generates a bias associated to the 
dynamic panel form of these estimations: the lagged value of the Polity score is mechanically correlated with the error term, yielding non consistent estimates. To take into account this econometric issue, we reproduce the specification shown in Column 4 using the Generalized Method-of-Moments Estimator proposed by Arellano and Bond (1991). This methodology relies on the first-differentiation of the estimated equation (which eliminates the country fixed effects), and instrumentation of the first-difference of the lagged Polity score by all its available further lags. Results are shown in Column 5. When we implement this methodology, the coefficients estimated for Mig - Study and Initially Autocratic x Mig - Study remain very stable, as compared to the fixed effects estimations. ${ }^{3,4}$

The results observed when we control for the previous tenure's average level of democracy suggest that the coefficient for studies abroad is not driven by migrants, among them future leaders, coming back when the tide starts turning. But it introduces an asymmetry in the measure of the past level of democracy given that the average level of democracy during the previous leader's tenure is calculated over varying time spans, depending on the number of years the previous leader spent in power. Alternatively, to capture the potential expectations of democratization by an emigrant soon-to-be leader, we replace the average Polity score during the previous leader's tenure by the average level of democracy during the five years preceding the arrival in power (Column 1, Table 6). Moreover, it is arguable that instead of the average level of democracy, it is the evolution of this level which drives emigrants' expectations of democratization. To take it into account, we control in Column 2 of Table 6 for the difference between the highest and lowest scores of democracy experienced by the country during the last five years. Finally, Column 3 of Table 6 presents a last alternative way to check that the impact of studies abroad is not driven by future leaders coming back when democratization starts, excluding from the sample leaders who reached power less than three years after their return from migration and thus potentially returned precisely in order to become the leader.

Consistently with the results presented in Table 5, the three tests proposed in Table 6 confirm that the coefficient for Initially Autocratic x Mig - Study is not driven by future leaders coming back to their country when democratization starts. The coefficient of interest indeed remains very stable, both in size and significance, thus enhancing the confidence in the fact that the mechanism emphasized by Channel 2 is not biasing our main result.

\footnotetext{
${ }^{3}$ The GMM specification yields roughly satisfying tests, however results have to be taken with caution given the relatively small number of observations.

${ }^{4}$ The GMM estimates remain stable when we successively remove the different sets of control variables (results available upon request).
} 
Table 6: Do future leaders come back from migration when the tide is turning?

\begin{tabular}{|c|c|c|c|}
\hline Dependent: Polity score & $(1)$ & $(2)$ & $(3)$ \\
\hline Initially Autocratic & $\begin{array}{c}-9.045^{* * *} \\
(0.957)\end{array}$ & $\begin{array}{c}-9.211^{* * *} \\
(1.016)\end{array}$ & $\begin{array}{c}-9.922^{* * *} \\
(0.958)\end{array}$ \\
\hline Mig - Study & $\begin{array}{l}-0.135 \\
(0.376)\end{array}$ & $\begin{array}{l}-0.165 \\
(0.403)\end{array}$ & $\begin{array}{c}-0.00911 \\
(0.402)\end{array}$ \\
\hline Initially Autocratic x Mig - Study & $\begin{array}{l}1.959^{* *} \\
(0.763)\end{array}$ & $\begin{array}{c}2.036^{* *} \\
(0.790)\end{array}$ & $\begin{array}{c}2.367^{* * *} \\
(0.805)\end{array}$ \\
\hline Mig - Exile & $\begin{array}{l}-0.118 \\
(0.543)\end{array}$ & $\begin{array}{l}-0.139 \\
(0.542)\end{array}$ & $\begin{array}{l}-0.807 \\
(0.629)\end{array}$ \\
\hline Initially Autocratic x Mig - Exile & $\begin{array}{c}0.741 \\
(1.108)\end{array}$ & $\begin{array}{c}0.498 \\
(1.094)\end{array}$ & $\begin{array}{l}2.866^{*} \\
(1.483)\end{array}$ \\
\hline Mig - Diplomacy & $\begin{array}{l}-0.486 \\
(0.669)\end{array}$ & $\begin{array}{l}-0.338 \\
(0.664)\end{array}$ & $\begin{array}{l}-0.725 \\
(0.798)\end{array}$ \\
\hline Initially Autocratic x Mig - Diplomacy & $\begin{array}{c}0.568 \\
(1.185)\end{array}$ & $\begin{array}{c}0.554 \\
(1.231)\end{array}$ & $\begin{array}{l}2.353^{*} \\
(1.382)\end{array}$ \\
\hline Mig - Military & $\begin{array}{c}0.258 \\
(0.852)\end{array}$ & $\begin{array}{c}0.145 \\
(0.840)\end{array}$ & $\begin{array}{c}-0.842 \\
(1.131)\end{array}$ \\
\hline Initially Autocratic x Mig - Military & $\begin{array}{c}0.832 \\
(0.849)\end{array}$ & $\begin{array}{c}0.858 \\
(0.883)\end{array}$ & $\begin{array}{c}1.211 \\
(0.989)\end{array}$ \\
\hline Polity score average - 5 years & $\begin{array}{c}0.117^{* * *} \\
(0.0415)\end{array}$ & & \\
\hline Polity score gap - 5 years & & $\begin{array}{c}0.0146 \\
(0.0368)\end{array}$ & \\
\hline Constant & $\begin{array}{c}-3.805^{* *} \\
(1.684)\end{array}$ & $\begin{array}{l}3.550^{*} \\
(1.920)\end{array}$ & $\begin{array}{c}7.402^{* * *} \\
(1.851)\end{array}$ \\
\hline Observations & 351 & 351 & 348 \\
\hline R-squared & 0.876 & 0.871 & 0.860 \\
\hline Number of countries & 103 & 103 & 105 \\
\hline Leader level controls & Yes & Yes & Yes \\
\hline Country level controls & Yes & Yes & Yes \\
\hline Profession dummies & Yes & Yes & Yes \\
\hline Country dummies & Yes & Yes & Yes \\
\hline Year dummies & Yes & Yes & Yes \\
\hline
\end{tabular}

\section{$7 \quad$ The selection into migration}

The two previous sections provide evidence that the positive correlation between studies abroad and democracy is not driven by the two first channels identified in Section 4: potential preference of democratic countries for return migrants, and future leaders coming back in their country when they witness the first signs of democratization. 
This section aims at dealing with the third major source of potential endogeneity in the "migration of the leader - democracy" nexus, namely individual selection into migration. It is clear that migrants are self-selected. In this perspective, they may have specific characteristics that both make them more likely to choose to study abroad, and more likely to be democrat. It is hardly feasible to control directly for all these characteristics, many of them being unobservable or difficult to measure (e.g. open-mindedness, taste for democracy, etc.). Alternatively, we propose here a simple empirical exercise to mitigate the selection bias.

In Table 7, we re-iterate the benchmark estimates (Table 3) trying to isolate the choice of migration, which may be correlated with the individual characteristics simultaneously affecting the propensity to migrate and to be democrat, and the impact of the migration experience. To do so, we rely on two tools. First, for each migration experience, we introduce a dummy indicating if the leader migrated before being 15 years old. In these cases, the choice of migrating, in all likelihood, was not made by the future leader himself but rather by his parents. Moreover, to capture the unobserved characteristics of the leader that may be inherited from his family, we also control for a dummy variable that equals one if the profession of the leader's father was skilled.

As shown in Table 7, the coefficient associated with the dummy for the occupation of the leader's father is always positive, its statistical significance depending on the specification. This positive correlation suggests that leaders whose father's occupation is skilled are associated with a higher level of democracy in average. The coefficient associated with studies abroad, considering only leaders who migrated aged 14 or earlier, is very stable in size as compared to the benchmark estimates. It only looses significance (with a p-value of 0.198) in the most demanding specification presented in Column (4). Note that, due to the introduction of new variables which are not available for all leaders, the number of observations is lowered in this Table.

The results observed when focusing on early migration experiences and controlling for the leader's inherited social capital (proxied by the occupation of his father) suggest that selection is indeed at play in the "migration of the leader - democracy" nexus, but does not completely drives the observed positive correlation between studies abroad and democratization. 
Table 7: Selection into migration

\begin{tabular}{|c|c|c|c|c|}
\hline Dependent: Polity Score & (1) & $(2)$ & (3) & $(4)$ \\
\hline Migration Early & $\begin{array}{l}-1.017 \\
(1.211)\end{array}$ & & & \\
\hline Mig - Study Early & & $\begin{array}{l}1.798^{*} \\
(0.917)\end{array}$ & $\begin{array}{l}2.082^{*} \\
(1.169)\end{array}$ & $\begin{array}{c}2.012^{\dagger} \\
(1.553)\end{array}$ \\
\hline Mig - Military Early & & $\begin{array}{l}-1.594 \\
(2.608)\end{array}$ & $\begin{array}{c}-4.889^{* *} \\
(2.048)\end{array}$ & $\begin{array}{c}-3.664^{*} \\
(2.033)\end{array}$ \\
\hline Mig - Exile Early & & $\begin{array}{c}-3.117^{*} \\
(1.611)\end{array}$ & $\begin{array}{c}-4.906^{* * *} \\
(1.393)\end{array}$ & $\begin{array}{c}-3.530^{*} \\
(1.969)\end{array}$ \\
\hline Fatherprof_skil & $\begin{array}{c}0.805^{*} \\
(0.466)\end{array}$ & $\begin{array}{c}0.529 \\
(0.526)\end{array}$ & $\begin{array}{l}1.003^{* *} \\
(0.472)\end{array}$ & $\begin{array}{c}0.936 \\
(0.681)\end{array}$ \\
\hline Constant & $\begin{array}{l}6.660^{*} \\
(3.590)\end{array}$ & $\begin{array}{c}9.846^{* * * *} \\
(3.164)\end{array}$ & $\begin{array}{l}8.000^{*} \\
(4.211)\end{array}$ & $\begin{array}{l}-1.049 \\
(4.604)\end{array}$ \\
\hline Observations & 326 & 326 & 235 & 217 \\
\hline R-squared & 0.605 & 0.679 & 0.711 & 0.751 \\
\hline Number of countries & 108 & 108 & 91 & 85 \\
\hline Leader level controls & Yes & Yes & Yes & Yes \\
\hline Country level controls & No & No & Yes & Yes \\
\hline Profession dummies & No & No & No & Yes \\
\hline Migration variables & Yes & Yes & Yes & Yes \\
\hline Country dummies & Yes & Yes & Yes & Yes \\
\hline Year dummies & Yes & Yes & Yes & Yes \\
\hline $\begin{array}{l}\text { Robust standard errors in } \mathrm{p} \\
{ }_{* * *} \mathrm{p}<0.01,{ }^{* *} \mathrm{p}<0.05,{ }^{*} \mathrm{p} \\
\text { Leader level controls refer to } \\
\text { try level controls refer to: } \\
\text { and Students abroad norma } \\
\text { The variable "Mig - Diplon } \\
\text { sample migrated for diplom } \\
\dagger \mathrm{p} \text {-val }=0.198 .\end{array}$ & $\begin{array}{l}\text { arentheses } \\
\text { K0.1. } \\
\text { Tenure d } \\
\text { DP pc gr } \\
\text { ized by pc } \\
\text { acy Early' }\end{array}$ & $\begin{array}{l}\text { lustered at } \\
\text { ation, Won } \\
\text { vth (tenure } \\
\text { ulation. } \\
\text { s dropped }\end{array}$ & $\begin{array}{l}\text { e country leve } \\
\text { High Educat } \\
\text { Emig, Skilled } \\
\text { e since no le } \\
\text { of } 15 \text {. }\end{array}$ & $\begin{array}{l}\text { Emig, Coun- } \\
\text { Emig, Pop } \\
\text { ader in our }\end{array}$ \\
\hline
\end{tabular}

\section{Robustness tests}

The fact that the leader studied abroad is positively and significantly associated with democracy during his tenure, and the three previous sections provided evidence that this correlation is not driven by the three first mechanisms identified in Section 4. On the contrary, the results suggest that leaders who studied abroad before reaching power have a democratizing effect in countries with an initial low level of quality of political institutions (Channel 4). Unfortunately, the data at hand do not allow us to test whether this impact is due to migration per se, or capturing a better quality of education abroad, or both. In this section, we provide four extensions to investigate further the main result. 


\subsection{Alternative outcomes}

First, one could wonder if we are here measuring the effective level of democracy during a leader's tenure or rather capturing a larger trend of democratization in the country, independent from individual leaders. Controlling for the past Polity score (Tables 5 and 6 , Section 6 ) was a first way to address this concern. To go further in the investigation of this question, we replicate the estimations on two alternative dependent variables:

- The difference between the highest and lowest Polity scores recorded during the tenure (Polity gap).

- The level of the Polity score measured the last year of the leader's tenure (Polity last).

In these estimations, we also control for the gap in the Polity score observed during the previous leader's tenure, Lagged Polity gap. Columns 1 to 4 of Table 8 display the results concerning the first alternative outcome, Polity gap. Lagged Polity gap has a negative and significant coefficient: countries in which the index of democracy has changed more during the previous leadership tend to see their level of democracy change less during the following leadership. In other words, after a transition, the countries of our sample tended to stabilize in average. Moreover, countries which started with an initial autocratic setting exhibit a more important average change in their level of democracy. In Columns 5 to 8 of Table 8 , the dependent variable is the level of democracy measured the last year of the tenure, Polity last. In this case, Lagged Polity gap also has a negative but non significant coefficient. Not surprisingly, countries which started with an initial autocratic setting exhibit a lower level of democracy at the end of the leader's tenure.

For both dependent variables, migration is not significant neither in initially democratic nor in initially autocratic countries. We also observe that Mig - Study is positively correlated with both outcomes when the tenure started in an autocratic environment, which is in line with our benchmark results. More precisely, the point estimates suggest that leaders who studied abroad are associated with an average change in the Polity score during their tenure between 2 and 3 points larger, and with a Polity score between 3 and 4 points higher when they leave power. It also appears in Columns 3 and 4 that leaders who experienced an exile tend to be associated with a larger (resp. lower) Polity gap when they reached power in a relatively democratic (resp. autocratic) setting, while leaders who migrated for diplomatic reasons are negatively correlated with democracy in initially democratic settings. These two types of migration experiences are not significantly correlated with the final level of democracy, Polity last. Finally, military migration is significantly associated with none of the two dependant variables. 
Table 8: Alternative outcomes

\begin{tabular}{|c|c|c|c|c|c|c|c|c|}
\hline & \multicolumn{4}{|c|}{ Polity delta } & \multicolumn{4}{|c|}{ Polity last } \\
\hline & $(1)$ & $(2)$ & $(3)$ & $(4)$ & $(5)$ & $(6)$ & (7) & (8) \\
\hline Lagged Polity Gap & $\begin{array}{c}-0.105^{* *} \\
(0.0409)\end{array}$ & $\begin{array}{c}-0.0959^{* *} \\
(0.0408)\end{array}$ & $\begin{array}{c}-0.105^{*} \\
(0.0546)\end{array}$ & $\begin{array}{c}-0.131^{* *} \\
(0.0585)\end{array}$ & $\begin{array}{c}0.0526 \\
(0.0567)\end{array}$ & $\begin{array}{c}0.0626 \\
(0.0588)\end{array}$ & $\begin{array}{c}0.0758 \\
(0.0498)\end{array}$ & $\begin{array}{c}0.0850 \\
(0.0591)\end{array}$ \\
\hline Initially Autocratic & $\begin{array}{c}1.003 \\
(0.852)\end{array}$ & $\begin{array}{c}0.574 \\
(0.761)\end{array}$ & $\begin{array}{c}0.794 \\
(1.273)\end{array}$ & $\begin{array}{c}0.0501 \\
(1.274)\end{array}$ & $\begin{array}{c}-7.238^{* * *} \\
(1.329)\end{array}$ & $\begin{array}{c}-7.619^{* * *} \\
(1.206)\end{array}$ & $\begin{array}{c}-6.814^{* * *} \\
(1.701)\end{array}$ & $\begin{array}{c}-6.678^{* * *} \\
(1.835)\end{array}$ \\
\hline Migration & $\begin{array}{l}0.0619 \\
(0.430)\end{array}$ & & & & $\begin{array}{c}-0.656 \\
(0.606)\end{array}$ & & & \\
\hline Initially Autocratic x Migration & $\begin{array}{c}0.377 \\
(0.901)\end{array}$ & & & & $\begin{array}{c}1.818 \\
(1.149)\end{array}$ & & & \\
\hline Mig - Study & & $\begin{array}{l}-0.155 \\
(0.475)\end{array}$ & $\begin{array}{l}-0.391 \\
(0.499)\end{array}$ & $\begin{array}{l}-0.526 \\
(0.461)\end{array}$ & & $\begin{array}{l}-0.825 \\
(0.521)\end{array}$ & $\begin{array}{c}-0.901^{*} \\
(0.532)\end{array}$ & $\begin{array}{l}-0.855 \\
(0.569)\end{array}$ \\
\hline Initially Autocratic x Mig - Study & & $\begin{array}{l}1.898^{* *} \\
(0.931)\end{array}$ & $\begin{array}{l}2.155^{*} \\
(1.240)\end{array}$ & $\begin{array}{c}1.968^{\dagger} \\
(1.306)\end{array}$ & & $\begin{array}{c}3.368^{* * *} \\
(1.127)\end{array}$ & $\begin{array}{c}4.077^{* * *} \\
(1.384)\end{array}$ & $\begin{array}{c}3.829 * * * \\
(1.385)\end{array}$ \\
\hline Mig - Exile & & $\begin{array}{c}0.189 \\
(0.667)\end{array}$ & $\begin{array}{c}0.247 \\
(0.877)\end{array}$ & $\begin{array}{c}0.738 \\
(0.934)\end{array}$ & & $\begin{array}{l}0.0638 \\
(0.807)\end{array}$ & $\begin{array}{c}0.838 \\
(0.747)\end{array}$ & $\begin{array}{c}0.635 \\
(0.771)\end{array}$ \\
\hline Initially Autocratic x Mig - Exile & & $\begin{array}{c}-0.0656 \\
(1.037)\end{array}$ & $\begin{array}{c}-0.646 \\
(1.349)\end{array}$ & $\begin{array}{c}0.393 \\
(1.457)\end{array}$ & & $\begin{array}{l}-0.891 \\
(1.257)\end{array}$ & $\begin{array}{l}-1.075 \\
(1.447)\end{array}$ & $\begin{array}{l}-1.098 \\
(1.562)\end{array}$ \\
\hline Mig - Diplomacy & & $\begin{array}{c}0.649 \\
(0.942)\end{array}$ & $\begin{array}{l}-0.145 \\
(0.873)\end{array}$ & $\begin{array}{r}-0.0621 \\
(0.822)\end{array}$ & & $\begin{array}{l}-1.341 \\
(1.021)\end{array}$ & $\begin{array}{l}-0.910 \\
(1.041)\end{array}$ & $\begin{array}{l}-1.133 \\
(1.120)\end{array}$ \\
\hline Initially Autocratic x Mig - Diplomacy & & $\begin{array}{l}-0.303 \\
(1.216)\end{array}$ & $\begin{array}{c}2.135 \\
(1.658)\end{array}$ & $\begin{array}{c}2.416 \\
(1.686)\end{array}$ & & $\begin{array}{l}1.826 \\
(1.436)\end{array}$ & $\begin{array}{c}0.665 \\
(1.639)\end{array}$ & $\begin{array}{c}1.612 \\
(1.957)\end{array}$ \\
\hline Mig - Military & & $\begin{array}{c}0.355 \\
(0.880)\end{array}$ & $\begin{array}{l}-0.390 \\
(0.766)\end{array}$ & $\begin{array}{l}-1.546 \\
(1.491)\end{array}$ & & $\begin{array}{l}-0.755 \\
(0.806)\end{array}$ & $\begin{array}{l}-0.882 \\
(0.755)\end{array}$ & $\begin{array}{l}-0.394 \\
(1.552)\end{array}$ \\
\hline Initially Autocratic x Mig - Military & & $\begin{array}{c}0.142 \\
(1.301)\end{array}$ & $\begin{array}{c}1.603 \\
(1.420)\end{array}$ & $\begin{array}{c}2.124 \\
(1.351)\end{array}$ & & $\begin{array}{l}1.536 \\
(1.062)\end{array}$ & $\begin{array}{l}1.600 \\
(1.338)\end{array}$ & $\begin{array}{c}2.008 \\
(1.349)\end{array}$ \\
\hline Constant & $\begin{array}{r}2.708^{* *} \\
(1.351)\end{array}$ & $\begin{array}{l}3.101^{* *} \\
(1.200)\end{array}$ & $\begin{array}{c}2.162 \\
(2.126)\end{array}$ & $\begin{array}{l}2.770 \\
(2.501)\end{array}$ & $\begin{array}{l}-0.438 \\
(1.913)\end{array}$ & $\begin{array}{c}0.389 \\
(2.111)\end{array}$ & $\begin{array}{l}0.795 \\
(2.694)\end{array}$ & $\begin{array}{l}-0.265 \\
(3.154)\end{array}$ \\
\hline Observations & 511 & 511 & 373 & 351 & 511 & 511 & 373 & 351 \\
\hline R-squared & 0.280 & 0.294 & 0.436 & 0.495 & 0.589 & 0.604 & 0.615 & 0.639 \\
\hline Number of countries & 115 & 115 & 105 & 102 & 115 & 115 & 105 & 102 \\
\hline Leader level controls & Yes & Yes & Yes & Yes & Yes & Yes & Yes & Yes \\
\hline Country level controls & No & No & Yes & Yes & No & No & Yes & Yes \\
\hline Profession dummies & No & No & No & Yes & No & No & No & Yes \\
\hline Country dummies & Yes & Yes & Yes & Yes & Yes & Yes & Yes & Yes \\
\hline Year dummies & Yes & Yes & Yes & Yes & Yes & Yes & Yes & Yes \\
\hline
\end{tabular}

Robust standard errors in parentheses, clustered at the country level. $* * * \mathrm{p}<0.01, * * \mathrm{p}<0.05, * \mathrm{p}<0.1$.

Leader level controls refer to: Tenure duration, Woman, High Education. Country level controls refer to: GDP pc growth (tenure), Emig,

Skilled Emig, Pop and Students abroad normalized by population.

${ }^{\dagger} \mathrm{p}-\mathrm{val}=0.141$. 


\subsection{Falsification test}

If the effect that is at play here is that studies abroad make leaders more likely to promote democracy in their country, we should not observe any significant correlation between Mig - Study and the level of democracy of the country measured the year of the leader's arrival in power (Initial Polity score). Indeed, democratization implies structural reforms that require enough time to translate into an increase of the Polity score. This falsification exercise also provides an alternative test for the "democracies' preferences" channel tackled in Section 5. If a process of selection is at play in the positive coefficient observed for studies abroad, we would expect a similar coefficient when using the initial level of democracy as dependant variable. Such a result would suggest that democracies have a higher propensity to select leaders who studied abroad, symmetrically to Besley and Reynal-Querol (2011) who find a higher propensity of democracies to select educated leaders.

This test is displayed in Table 9. Consistently with our interpretation of the benchmark results, the coefficient associated with migration, as well as the coefficients associated with foreign studies, migration for diplomatic reasons, and exile, are not significant. Leaders who migrated for their studies are found to positively affect the level of democracy in their country during the period when they are in power, but the causation is not working the other way round: democracies do not tend to select leaders with an education experience abroad. On the contrary, there is a negative significant correlation between the leader's military background (either considering his migration experience or his profession) and the level of democracy in the year of his arrival, suggesting that democratic countries have a lower preference for militaries. This falsification test reinforces the confidence in the interpretation of the main finding, according to which leaders who studied abroad are more prone to democratize their country (Channel 4).

\subsection{Competing stories}

The positive impact of the leader having studied abroad on democratization is not driven by democracies having a higher preference for return migrants, nor by future leaders coming back when democratization starts, nor by unobservable individual characteristics driving both the decision to study abroad and the taste for democracy. We also provided evidence that this result still holds when we focus on the evolution of democracy during the tenure (rather than on its average), as well as on the level reached at the end of the tenure. 
Table 9: Falsification test

\begin{tabular}{|c|c|c|c|c|}
\hline Dependent: Lagged Polity score & (1) & $(2)$ & $(3)$ & (4) \\
\hline Migration & $\begin{array}{c}-0.967 \\
(0.716)\end{array}$ & & & \\
\hline Mig - Study & & $\begin{array}{c}0.348 \\
(0.587)\end{array}$ & $\begin{array}{c}-0.0734 \\
(0.637)\end{array}$ & $\begin{array}{l}-0.495 \\
(0.722)\end{array}$ \\
\hline Mig - Exile & & $\begin{array}{l}0.0420 \\
(0.613)\end{array}$ & $\begin{array}{c}0.138 \\
(0.630)\end{array}$ & $\begin{array}{l}-0.192 \\
(0.742)\end{array}$ \\
\hline Mig - Diplomacy & & $\begin{array}{l}-0.419 \\
(0.772)\end{array}$ & $\begin{array}{c}1.099 \\
(0.780)\end{array}$ & $\begin{array}{c}1.077 \\
(0.855)\end{array}$ \\
\hline Mig - Military & & $\begin{array}{c}-2.092^{* * *} \\
(0.716)\end{array}$ & $\begin{array}{c}-2.507^{* * *} \\
(0.891)\end{array}$ & $\begin{array}{l}-1.242 \\
(1.386)\end{array}$ \\
\hline Constant & $\begin{array}{c}0.758 \\
(1.209)\end{array}$ & $\begin{array}{l}-1.262 \\
(1.594)\end{array}$ & $\begin{array}{l}-1.228 \\
(2.578)\end{array}$ & $\begin{array}{c}1.169 \\
(3.642)\end{array}$ \\
\hline Observations & 517 & 517 & 378 & 355 \\
\hline R-squared & 0.360 & 0.373 & 0.460 & 0.507 \\
\hline Number of countries & 115 & 115 & 106 & 104 \\
\hline Leader level controls & Yes & Yes & Yes & Yes \\
\hline Country level controls & No & No & Yes & Yes \\
\hline Profession dummies & No & No & No & Yes \\
\hline Country dummies & Yes & Yes & Yes & Yes \\
\hline Year dummies & Yes & Yes & Yes & Yes \\
\hline
\end{tabular}

Two other competing stories can still be imagined when thinking about the link between leaders' studies abroad and democracy. The first one concerns nepotism. Indeed, in a country where nepotism is widespread, it is plausible that individuals who are potential future leaders and have access to the political networks take their decisions of migration while they already know that they have a high probability to reach power. This is likely to bias our results. ${ }^{5}$ To check this, we introduce in Columns 1 to 4 of Table 10 a dummy equaling one if the leader has a familial link with one of the previous leaders of the country. This variable proxies for nepotism and dynastic political systems. In our sample, around $10 \%$ of the leaders had indeed a familial relationship with a past leader, as such this is not a marginal phenomenon over the period and countries of analysis. Family Link is never significantly associated with democracy in the estimations, while the results regarding studies abroad remain very stable.

\footnotetext{
${ }^{5}$ Nevertheless, it is reasonable to believe that this bias would work against us, given that leaders who reach power in a context of widespread nepotism generally do not exhibit high levels of democracy.
} 
Table 10: Competing Stories

\begin{tabular}{lcccccccc}
\hline Dependent: Polity Score & $(1)$ & $(2)$ & $(3)$ & $(4)$ & $(5)$ & $(6)$ & $(7)$ & $(8)$ \\
\hline & & & & & & & & \\
Migration & -0.443 & & & & -0.441 & & & \\
& $(0.445)$ & & & & $(0.449)$ & & & \\
Mig - Study & & $0.764^{*}$ & $1.370^{* * *}$ & $1.273^{* *}$ & & $0.771^{*}$ & $1.365^{* * *}$ & $1.277^{* *}$ \\
& & $(0.440)$ & $(0.492)$ & $(0.501)$ & & $(0.443)$ & $(0.490)$ & $(0.500)$ \\
Mig - Exile & & $0.952^{* *}$ & $1.050^{* *}$ & 0.0394 & & $0.998^{* *}$ & $1.021^{* *}$ & -0.0165 \\
& & $(0.431)$ & $(0.445)$ & $(0.522)$ & & $(0.429)$ & $(0.442)$ & $(0.505)$ \\
Mig - Diplomacy & & -0.801 & -0.351 & -0.523 & & -0.843 & -0.309 & -0.476 \\
& & $(0.618)$ & $(0.779)$ & $(0.759)$ & & $(0.612)$ & $(0.759)$ & $(0.750)$ \\
Mig - Military & & $-2.714^{* * *}$ & $-3.937^{* * *}$ & 0.0860 & & $-2.716^{* * *}$ & $-3.900^{* * *}$ & 0.116 \\
& & $(0.690)$ & $(0.780)$ & $(1.227)$ & & $(0.695)$ & $(0.803)$ & $(1.263)$ \\
Family Link & 0.493 & 0.423 & -0.307 & -0.441 & & & & \\
& $(0.473)$ & $(0.534)$ & $(0.661)$ & $(0.672)$ & & & & \\
Foreign Imposition & & & & & 0.240 & -0.779 & 0.681 & 1.117 \\
& & & & $(1.519)$ & $(1.561)$ & $(2.179)$ & $(2.146)$ \\
Constant & 1.042 & -1.087 & $-7.340^{* * *}$ & 2.795 & 1.096 & -1.053 & 3.222 & 2.613 \\
& $(1.332)$ & $(1.369)$ & $(2.003)$ & $(2.356)$ & $(1.336)$ & $(1.372)$ & $(1.970)$ & $(2.269)$ \\
& & & & & & & & \\
Observations & 577 & 577 & 403 & 377 & 577 & 577 & 403 & 377 \\
R-squared & 0.511 & 0.554 & 0.614 & 0.644 & 0.510 & 0.554 & 0.614 & 0.644 \\
Number of countries & 125 & 125 & 110 & 106 & 125 & 125 & 110 & 106 \\
Leader level controls & Yes & Yes & Yes & Yes & Yes & Yes & Yes & Yes \\
Country level controls & Yes & Yes & Yes & Yes & Yes & Yes & Yes & Yes \\
Profession dummies & Yes & Yes & Yes & Yes & Yes & Yes & Yes & Yes \\
Country FE & Yes & Yes & Yes & Yes & Yes & Yes & Yes & Yes \\
Year FE & Yes & Yes & Yes & Yes & Yes & Yes & Yes & Yes \\
\hline
\end{tabular}

Robust standard errors in parentheses, clustered at the country level. ${ }^{* * *} \mathrm{p}<0.01,{ }^{* *} \mathrm{p}<0.05,{ }^{*} \mathrm{p}<0.1$.

Leader level controls refer to: Tenure duration, Woman, High Education. Country level controls refer to: GDP pc growth (tenure), Emig, Skilled Emig, Pop and Students abroad normalized by population. 
Second, one could think about the geopolitical relationships between countries as an important potential omitted variable. Indeed, some leaders in the developing world have been imposed by external countries in the last decades (around 1.6\% of the leaders observed in the sample have reached power in such conditions). In those specific cases, it is highly probable that among the potential leaders to be chosen, the foreign country will prefer the candidate who came for studying. Again, this could bias the estimated link between studies abroad and democracy. To control for this, we introduce in Column 5 to 8 of Table 10 a dummy variable equaling one if the leader has been imposed by a foreign country. This variable comes from the Archigos dataset. Here again, our main results regarding studies abroad are unchanged, while the coefficient associated with Foreign Imposition is not significant.

\subsection{Year-level panel}

All the results presented above emanate from a panel data set built at the leader level: each line in the database corresponds to one leader in one country. One could suspect that this design of the data leads to a bias in the estimated coefficients, given that leaders who stayed in power for a longer period are given the same weight as leaders who stayed shortly, by construction. To ensure that our results are not driven by this, we re-build our data set making each line corresponding to one year. In this case, leaders are observed as many times as the number of years they spent in power. Annex D reiterates the benchmark estimations of Table 3 on this alternative database. It confirms our previous results: leaders who studied abroad appear to be positively correlated with the level of democracy, measured in this case on a yearly basis.

\section{Conclusion}

This paper presents original data on the individual characteristics of leaders in developing countries over the 1960-2004 period, and in particular on their migration history. Thanks to these new data we put forward a positive impact of the fact that the leader studied abroad on the quality of political institutions in the country he's at the head of. This effect is independent from the level of education reached.

We show that the effect of the leader having studied abroad on political institutions is driven by countries which start from a low level of democracy. This is inconsistent with the idea that the positive correlation between education abroad and democracy could be due to a higher propensity of democratic countries to choose return migrants as leaders. We also check that our main result is not explained by the fact that future leaders come back to their country of origin when it starts democratizing. Moreover, we provide evidence 
that self-selection into migration is not driving the benchmark result either.

The main result of this paper is confirmed by various robustness checks. This finding complements the literature on the impact of political leaders' individual characteristics, focused on education and occupation. It is also in line with the literature regarding the impact of migration on politics in the origin country, which suggests important diffusion effects regarding political preferences triggered by migration. Our results thus propose a new channel - the political elites - through which these diffusion effects may occur, and through which migration may be a tool of soft power in the perspective of democratization in developing countries. 


\section{References}

Adolph, C.A. 2004. The dilemma of discretion: Career ambitions and the politics of central banking. Ph.D. thesis, Harvard University.

Arellano, M. and S. Bond. 1991. "Some tests of specification for panel data: Monte Carlo evidence and an application to employment equations." The Review of Economic Studies 58 (2):277-297.

Batista, C. and P.C. Vicente. 2011. "Do migrants improve governance at home? Evidence from a voting experiment." The World Bank Economic Review 25 (1):77-104.

Bertrand, M. and A. Schoar. 2003. "Managing with style: The effect of managers on firm policies." The Quarterly Journal of Economics 118 (4):1169-1208.

Besley, T., J.G. Montalvo, and M. Reynal-Querol. 2011. "Do Educated Leaders Matter?" The Economic Journal 121 (554):F205-227.

Besley, T. and M. Reynal-Querol. 2011. "Do democracies select more educated leaders?" American political science review 105 (3):552-566.

Chattopadhyay, R. and E. Duflo. 2004. "Women as policy makers: Evidence from a randomized policy experiment in India." Econometrica 72 (5):1409-1443.

Chauvet, L. and M. Mercier. 2013. "Do return migrants transfer political norms to their origin country? Evidence from Mali." DIAL - PSE Mimeo .

Defoort, C. 2008. "Long-term trends in international migration: an analysis of the six main receiving countries." Population (english edition) 63 (2):285-317.

Docquier, F., E. Lodigiani, H. Rapoport, and M. Schiff. 2011. "Emigration and democracy." Centro Studi Luca d'Agliano Development Studies Working Paper (307).

Dreher, A., M.J. Lamla, S.M. Lein, and F. Somogyi. 2009. "The impact of political leaders' profession and education on reforms." Journal of Comparative Economics 37 (1):169-193.

Fair, R.C. 1978. "The effect of economic events on votes for president." The Review of Economics and Statistics 60 (2):159-173.

Franck, R. and I. Rainer. 2012. "Does the Leader's Ethnicity Matter? Ethnic Favoritism, Education, and Health in Sub-Saharan Africa." American Political Science Review 106 (2):294-325. 
Goemans, H.E., K.S. Gleditsch, and G. Chiozza. 2009. "Introducing Archigos: A dataset of political leaders." Journal of Peace research 46 (2):269-283.

Göhlmann, S. and R. Vaubel. 2007. "The educational and occupational background of central bankers and its effect on inflation: An empirical analysis." European Economic Review 51 (4):925-941.

Gwartney, J., R. Lawson, and S. Norton. 2008. Economic Freedom of the World 2008 Annual Report. The Fraser Institute.

Jones, B.F. and B.A. Olken. 2005. "Do leaders matter? National leadership and growth since World War II." The Quarterly Journal of Economics 120 (3):835-864.

Lodigiani, E. and S. Salomone. 2012. "Migration-induced Transfers of Norms. The case of Female Political Empowerment." Tech. rep., Université catholique de Louvain, Institut de Recherches Economiques et Sociales (IRES).

Marshall, M.G. and K. Jaggers. 2002. "Polity IV project: Political regime characteristics and transitions, 1800-2002." .

Omar Mahmoud, T., H. Rapoport, A. Steinmayr, and C. Trebesch. 2012. "Emigration and political change." Mimeo .

Persson, P. and E. Zhuravskaya. 2011. "Elite capture in the absence of democracy: evidence from backgrounds of Chinese provincial leaders." Paris School of Economics Working Paper .

Pfutze, T. 2012. "Does migration promote democratization? Evidence from the Mexican transition." Journal of Comparative Economics .

Spilimbergo, A. 2009. "Democracy and foreign education." American Economic Review 99 (1):528-43. 


\section{Appendices}

Annex A: Differences between leaders who stayed more or less than one year in power

Table A

\begin{tabular}{lccc}
\hline & Difference & $(t$ statistics $)$ & Observations \\
\hline Woman & -0.0123 & $(1.06)$ & 932 \\
Age at arrival & $-2.224^{* * *}$ & $(2.74)$ & $926^{a}$ \\
Tenure Duration & $2590.7^{* * *}$ & $(-14.63)$ & 932 \\
High Education & $-0.0728^{*}$ & $(1.73)$ & 775 \\
Military & $-0.0821^{* *}$ & $(2.24)$ & 792 \\
Law & -0.00819 & $(0.25)$ & 792 \\
Eco & -0.00450 & $(0.20)$ & 792 \\
Health & -0.00700 & $(0.40)$ & 792 \\
Admin & 0.0106 & $(-0.46)$ & 792 \\
Academics & 0.0302 & $(-1.08)$ & 792 \\
Worker & $0.0325^{* *}$ & $(-2.20)$ & 792 \\
Religious & -0.00129 & $(0.14)$ & 792 \\
Scientist & 0.00893 & $(-0.39)$ & 792 \\
Business & 0.0211 & $(-1.24)$ & 792 \\
Migration & 0.0437 & $(-1.11)$ & 786 \\
Mig - Diplomacy & $-0.0544 *$ & $(1.93)$ & 786 \\
Mig - Study & 0.0359 & $(-0.86)$ & 786 \\
Mig - Exile & $0.0484 *$ & $(-1.67)$ & 786 \\
Mig - Military & -0.00582 & $(0.18)$ & 786 \\
Migration Duration & 0.747 & $(-0.65)$ & 373 \\
\hline
\end{tabular}

${ }^{* * *} \mathrm{p}<0.01,{ }^{* *} \mathrm{p}<0.05,{ }^{*} \mathrm{p}<0.1$.

${ }^{a}$ The date of birth of six leaders of the sample are not available. 
Annex B: Attrition issue

Among the sample of 679 leaders who stayed more than one year in power, we do not have information on migration for 69 of them. In the following table, we re-iterate the benchmark estimations presented in Table 3 by treating these 69 leaders as non-migrants. Indeed, it is more plausible that those missing values equal 0, given that we rarely can directly read in a leader's biography that "he never migrated".

Table B

\begin{tabular}{lcccc}
\hline Dependent: Polity Score & $(1)$ & $(2)$ & $(3)$ & $(4)$ \\
\hline Migration & -0.442 & & & \\
& $(0.425)$ & & & \\
Mig - Study & & $0.827^{* *}$ & $1.325^{* * *}$ & $1.184^{* *}$ \\
& & $(0.411)$ & $(0.480)$ & $(0.506)$ \\
Mig - Exile & & $0.957^{* *}$ & $1.153^{* * *}$ & 0.251 \\
& & $(0.440)$ & $(0.429)$ & $(0.531)$ \\
Mig - Diplomacy & & -0.790 & -0.195 & -0.363 \\
& & $(0.618)$ & $(0.698)$ & $(0.696)$ \\
Mig - Military & & $-2.788^{* * *}$ & $-3.873^{* * *}$ & 0.00578 \\
& $(0.681)$ & $(0.759)$ & $(1.143)$ \\
Constant & & -1.055 & $-8.459^{* * *}$ & 2.852 \\
& $(1.334)$ & $(1.352)$ & $(1.985)$ & $(2.203)$ \\
& & & & \\
Observations & 604 & 604 & 417 & 390 \\
R-squared & 0.493 & 0.539 & 0.606 & 0.635 \\
Number of countries & 125 & 125 & 110 & 106 \\
Leader level controls & Yes & Yes & Yes & Yes \\
Country level controls & No & No & Yes & Yes \\
Profession dummies & No & No & No & Yes \\
Country FE & Yes & Yes & Yes & Yes \\
Year FE & Yes & Yes & Yes & Yes \\
\hline
\end{tabular}

Robust standard errors in parentheses, clustered at the country level.

$* * * \mathrm{p}<0.01, * * \mathrm{p}<0.05,{ }^{*} \mathrm{p}<0.1$.

Leader level controls refer to: Tenure duration, Woman, High Education. Country level controls refer to: GDP pc growth (tenure), Emig, Skilled Emig, Pop and Students abroad normalized by population. 
Annex C: Correlation table between migration experiences and professional background

Table C

\begin{tabular}{|c|c|c|c|c|c|}
\hline & Migration & Mig - Study & Mig - Exile & Mig - Diplomacy & Mig - Military \\
\hline Mig - Study & $0.608^{* * *}$ & & & & \\
\hline Mig - Exile & $0.309^{* * *}$ & $0.108^{* * *}$ & & & \\
\hline Mig - Diplomacy & $0.262^{* * *}$ & $-0.076^{*}$ & -0.042 & & \\
\hline Mig - Military & $0.330 * * *$ & $-0.110^{* * *}$ & -0.060 & $0.073^{*}$ & \\
\hline Military & $0.158 * * *$ & $-0.238^{* * *}$ & $-0.122^{* * *}$ & $0.103^{* * *}$ & $0.740^{* * *}$ \\
\hline Law & $-0.128 * * *$ & -0.033 & $0.069^{*}$ & -0.024 & $-0.224^{* * *}$ \\
\hline Eco & 0.006 & $0.120^{* * *}$ & $-0.070^{*}$ & -0.034 & $-0.127 * * *$ \\
\hline Health & $0.083^{* *}$ & $0.150 * * *$ & -0.024 & -0.033 & $-0.086^{* *}$ \\
\hline Admin & 0.001 & 0.033 & -0.011 & $0.082^{* *}$ & $-0.132^{* * *}$ \\
\hline Academics & -0.014 & $0.117^{* * *}$ & -0.014 & $-0.068^{*}$ & $-0.178^{* * *}$ \\
\hline Business & -0.041 & 0.023 & 0.057 & -0.061 & $-0.071^{*}$ \\
\hline Religious & -0.001 & 0.003 & $0.101^{* *}$ & -0.046 & -0.060 \\
\hline Scientist & 0.013 & $0.135^{* * *}$ & $0.067^{*}$ & -0.037 & $-0.089 * *$ \\
\hline Worker & $-0.155^{* * *}$ & $-0.131^{* * *}$ & 0.052 & -0.053 & $-0.102^{* *}$ \\
\hline
\end{tabular}

$* * * \mathrm{p}<0.01,{ }^{* *} \mathrm{p}<0.05,{ }^{*} \mathrm{p}<0.1$. 
Annex D: Year-level panel

We re-iterate here the benchmark estimations presented in Table 3 on an alternative database where each line corresponds to a country-year pair (versus each line corresponding to a country-leader pair in the initial data).

Table D

\begin{tabular}{lcccc}
\hline Dependent: Polity Score & $(1)$ & $(2)$ & $(3)$ & $(4)$ \\
\hline Migration & & & & \\
& -0.223 & & & \\
Mig - Study & $(0.479)$ & & & \\
& & $0.923^{* *}$ & $1.347^{* *}$ & $1.195^{* *}$ \\
Mig - Exile & & $(0.448)$ & $(0.560)$ & $(0.601)$ \\
& & 0.590 & $1.274^{* *}$ & 0.471 \\
Mig - Diplomacy & & $(0.527)$ & $(0.493)$ & $(0.590)$ \\
& & -0.503 & -0.0982 & -0.175 \\
Mig - Military & & $-2.608^{* * *}$ & $-3.853^{* * *}$ & -0.821 \\
& & $(0.632)$ & $(0.678)$ & $(1.062)$ \\
Constant & -0.423 & -0.510 & 1.244 & $3.692^{* * *}$ \\
& $(3.020)$ & $(2.398)$ & $(1.053)$ & $(1.241)$ \\
& & & & \\
Observations & 4,386 & 4,386 & 2,596 & 2,400 \\
R-squared & 0.431 & 0.471 & 0.567 & 0.585 \\
Number of countries & 125 & 125 & 115 & 111 \\
Leader level controls & Yes & Yes & Yes & Yes \\
Country level controls & No & No & Yes & Yes \\
Profession dummies & No & No & No & Yes \\
Country FE & Yes & Yes & Yes & Yes \\
Year FE & Yes & Yes & Yes & Yes \\
\hline
\end{tabular}

Robust standard errors in parentheses, clustered at the country level.

$* * * \mathrm{p}<0.01,{ }^{*} * \mathrm{p}<0.05, * \mathrm{p}<0.1$.

Leader level controls refer to: Tenure duration, Woman, High Education. Country level controls refer to: Annual GDP pc growth, Emig, Skilled Emig, Pop and Students abroad normalized by population. 